\title{
Sığırlarda Oküler ve Perioküler Tümörlerin Klinik ve Histopatolojik
}

\author{
Değerlendirilmesi
}

\author{
Ünal YAVUZ ${ }^{1 *}$, Nihat YUMUŞAK² \\ ${ }^{1}$ Harran Üniversitesi, Veteriner Fakültesi, Cerrahi Anabilim Dalı, Şanlıurfa, Türkiye. \\ ${ }^{2}$ Harran Üniversitesi, Veteriner Fakültesi, Patoloji Anabilim Dalı, Şanlıurfa, Türkiye.
}

Geliş Tarihi: 16.01.2017

Kabul Tarihi: 15.02.2017

\begin{abstract}
Özet: Bu çalışmada oküler ve perioküler tümörlü 9 sığırın klinik ve histopatolojik özellikleri ile uygulanan eksizyon ve enüklasyon sonuçlarının değerlendirilmesi amaçlandı. Tedavi amacıyla 4 vakada lokal tümör eksizyonu ve 4 vakada göz enüklasyonu uygulanırken 1 vakada bulbus okuli ve çevre dokulardaki geniş tümör invazyonlarından dolayı kesime sevk önerildi. Histopatolojik muayenede 4 vakada yassı hücreli kanser, 2 vakada indiferensiye yassı hücreli kanser, 1 vakada melanom ve 2 vakada malign melanom tespit edildi. Oküler ve perioküler tümörlerin farklı ırklarda görülmesine rağmen en fazla Holstein ırkında karşılaşıldığı saptandı. Ayrıca vakaların çoğunun yassı hücreli kanser olması da dikkat çekti. Etkilenen hayvanların tamamının dişi ve ortalama yaş aralığının 4.78 olduğu gözlendi. Opere edilen hayvanlar ortalama 6 aya kadar takip edildi ve nüks veya metastaz yönünden net bir bulguyla karşılaşılmadı. Sonuç olarak oküler ve perioküler tümörlerin tedavisinde eksizyon ve enüklasyon maliyeti düşük, basit ve az ekipmanla kolay uygulanabilir cerrahi yöntemlerdir. Ayrıca bu yöntemlerin oküler ve perioküler tümörlerde ağrıyı azaltmak, hayvanın yaşam kalitesini yükseltmek, verim süresini arttırmak ve ekonomik kayıpları azaltmak amacıyla kullanılabileceği gösterilmiştir.
\end{abstract}

Anahtar Kelimeler: Eksizyon, Enüklasyon, Oküler Tümör, Sığır.

\section{Clinical and Histopathological Evaluation of Bovine Ocular and Periocular Tumors}

\begin{abstract}
In this study, we aimed to evaluate clinical and histopathological features and the results of applied excision and enuclation of ocular and periocular tumors in 9 cattle For treatment purposes, local excision of the tumor in 4 cases and eye enucleation in 4 cases were applied. In one case, slaughter was recommended because of the extensive tumor invasion of bulbus oculi and surrounding tissues. Squamous cell carcinoma in 4 cases, indifferential squamous cell carcinoma in 2 cases, melanoma in 1 case and malign melanoma in 2 cases were detected in the histopathological examination. Although the ocular and periocular tumors are seen in different breeds, it was noted that they were most encountered in Holstein breed. It was also noticed that the majority of the such cases were squamous cell carcinomas. It was observed that the entire affected animals were female and average age range was 4.78 years. Operated animals were followed approximately up to six months and no recurrence or metastasis was encountered during period. In conclusion, excision and enuclation in the treatment of ocular and periocular tumors are surgical methods that are simple, with low cost and easily performed with less equipment. In addition, these methods can be used to reduce of pain, improve the quality of life of the animal, increase the yield period and reduce economic losses in ocular and periocular tumors.

Keywords: Excision, Enuclation, Ocular Tumor, Cattle.
\end{abstract}

\section{Giriş}

Oküler ve perioküler tümörler orbita, gözkapakları, konjuktiva, kornea ve intraoküler dokularla bağlantılı olarak yapısal değişiklikler ile ağrıya neden olurlar. Gözün fonksiyonunu ve görüşü etkilediklerinden dolayı küçük tümörler bile önemli olarak kabul edilirler (Dubielzig, 2002). Tüm hayvan türlerinde görüldüğü, çiftlik hayvanı türleri arasında ise en sık sığırlarda karşılaşıldığı bildirilmiştir. Sığırlarda en fazla etkilenen bölge gözkapakları, kornea ve üçüncü göz kapağıdır (Canpolat ve ark., 2007; Martins ve Barros, 2014; Ozmen ve ark., 2016; Sabri ve ark., 2010; Tsujita ve Plummer, 2010).

Sığırlarda oküler ve perioküler dokularda karşılaşılan en yaygın tümörlerin kanser göz olarak da bilinen yassı hücreli kanser ve lenfosarkom olduğu bildirilmiştir (Crispin, 2005; Dubielzig, 2002; Gelatt, 2005; Gharagozlou ve ark., 2007;
Hirsbrunner ve ark., 1998; Martins ve Barros, 2014; Robert, 2002; Schulz ve Anderson, 2010). Daha nadir olarak melanom, lenfom, hemangioendotelyom, malignant hemangioendotelyom, skuamöz papillom, sebaseöz gland karsinom, fibrom, mastositom ve optik sinir nöroepitelyomuyla karşılaşılmaktadır (Gharagozlou ve ark., 2007; Martins ve Barros, 2014; Robert, 2002; Schulz ve Anderson, 2010; Wilcock, 1993). Orbital ve periorbital tümörlü sığırlarda tümörün lenf nodülleri, iç organlar, kaslar ve diğer dokulara metas-tazı durumunda kaşeksi, verim kaybı ve karkas kalitesinin düşmesinden dolayı önemli ekonomik kayıplar oluşmaktadır (Gelatt, 2005; Robert, 2002). Oküler ve perioküler lezyonların tedavisi amacıyla enuklasyon, kriyoterapi, hipertermi, radyasyon terapisi, immünoterapi veya 
bunların kombinasyonu kullanılabilir. Bulbus okulideki ileri lezyonları sınırlamak, ağrılı oftalmik lezyonları ortadan kaldırmak ve yassı hücreli kanser gibi tümörlerin ilerlemesini durdurmak için en sık kullanılan cerrahi yöntem enüklasyondur (Al-Asadi, 2012; Gelatt, 2005; Sağlıyan ve ark., 2010; Schulz ve Anderson, 2010). Bu çalışmada sığırlarda oküler ve perioküler tümörlerin klinik ve histopatolojik özelliklerinin değerlendirilmesi, tedavide uygulanan cerrahi eksizyon ve enüklasyon sonuçlarının aktarılması amaçlanmıştır.

\section{Materyal ve Metot}

Çalışmanın materyalini 2015-2016 yıllarında Harran Üniversitesi Veteriner Fakültesi cerrahi kliniğine oküler ve perioküler dokularda kitlesel oluşum şikâyetleriyle muayene ve tedavi için getirilen farklı ırk, yaş ve cinsiyetteki 9 adet sütçü sığır oluşturdu (Tablo 1). Bu çalışma klinik tanı amaçlı yapıldığından Etik Kurul Belgesine ihtiyaç duyulmamıştır.

Tablo 1. Oküler ve perioküler tümörlü 9 vakanın klinik ve histopatolojik özellikleri.

\begin{tabular}{|c|c|c|c|c|c|c|c|}
\hline \multirow{2}{*}{$\begin{array}{l}\text { Vaka } \\
\text { No. }\end{array}$} & \multirow{2}{*}{$\begin{array}{l}\text { Irk, Yaş, } \\
\text { Cinsiyet }\end{array}$} & \multicolumn{2}{|c|}{ Etkilenen Göz } & \multirow{2}{*}{$\begin{array}{c}\text { Tümörün Klinik } \\
\text { Görünümü }\end{array}$} & \multirow{2}{*}{$\begin{array}{c}\text { Histopatolojik } \\
\text { Tanı } \\
\end{array}$} & \multirow{2}{*}{ Tümör Lokalizasyonu } & \multirow{2}{*}{ Cerrahi Müdahale } \\
\hline & & Sağ & Sol & & & & \\
\hline 1 & $\begin{array}{l}\text { Güney Anadolu } \\
\text { Kırmızısı, } 2 \text { Yaş, } \\
q \\
\end{array}$ & & $x$ & $\begin{array}{l}\text { Nodüler ve } \\
\text { hemorajik }\end{array}$ & $\begin{array}{l}\text { Yassı Hücreli } \\
\text { Kanser }\end{array}$ & $\begin{array}{l}\text { Bulbar konjuktiva, } \\
\text { kornea, limbus }\end{array}$ & Enüklasyon \\
\hline 2 & $\begin{array}{l}\text { Holstein, } 4 \text { Yaş, } \\
q\end{array}$ & $x$ & & $\begin{array}{l}\text { Yüzeyden taşkın, } \\
\text { eroziv ülseratif ve } \\
\text { yer yer kanamalı }\end{array}$ & $\begin{array}{l}\text { İndiferensiye } \\
\text { Yassı Hücreli } \\
\text { Kanser }\end{array}$ & $\begin{array}{c}\text { Membrana niktitans ve } \\
\text { alt/üst palpebral } \\
\text { konjuktiva }\end{array}$ & Enüklasyon \\
\hline 3 & $\begin{array}{l}\text { Holstein } x \\
\text { Simental } \\
\text { Melezi, } 5 \text { Yaş, } q\end{array}$ & & $x$ & $\begin{array}{l}\text { Nodüler ve } \\
\text { hemorajik }\end{array}$ & Melanom & Alt palpebral konjuktiva & Lokal eksizyon \\
\hline 4 & $\begin{array}{l}\text { Montafon, } 5 \\
\text { Yaş, },+\end{array}$ & $x$ & & $\begin{array}{l}\text { Nodüler ve } \\
\text { hiperemik }\end{array}$ & $\begin{array}{c}\text { Malign } \\
\text { Melanom } \\
\end{array}$ & 3. göz kapağı & Lokal eksizyon \\
\hline 5 & $\begin{array}{l}\text { Holstein, } 4 \text { Yaş, } \\
+\end{array}$ & & $x$ & $\begin{array}{c}\text { Multilobuler ve } \\
\text { ülseratif }\end{array}$ & $\begin{array}{l}\text { Yassı Hücreli } \\
\text { Kanser }\end{array}$ & $\begin{array}{l}\text { 3. göz kapağı ve alt } \\
\text { palpebral konjuktiva }\end{array}$ & Lokal eksizyon \\
\hline 6 & $\begin{array}{l}\text { Holstein, } 8 \text { Yaş, } \\
\stackrel{+}{ }\end{array}$ & $x$ & & $\begin{array}{l}\text { Nodüler ve } \\
\text { hemorajik }\end{array}$ & $\begin{array}{l}\text { Yassı Hücreli } \\
\text { Kanser }\end{array}$ & $\begin{array}{c}\text { Membrana niktitans ve } \\
\text { alt/üst palpebral } \\
\text { konjuktiva }\end{array}$ & Enüklasyon \\
\hline 7 & $\begin{array}{l}\text { Holstein, } 6 \text { Yaş, } \\
+\end{array}$ & $x$ & & $\begin{array}{l}\text { Nodüler ve } \\
\text { hiperemik }\end{array}$ & $\begin{array}{l}\text { Yassı Hücreli } \\
\text { Kanser }\end{array}$ & $\begin{array}{l}\text { 3. göz kapağı ve alt/üst } \\
\text { palpebral konjuktiva }\end{array}$ & Enüklasyon \\
\hline 8 & $\begin{array}{l}\text { Holstein, } 4 \text { Yaş, } \\
+\end{array}$ & $x$ & & $\begin{array}{l}\text { Lobüler ve } \\
\text { ülseratif }\end{array}$ & $\begin{array}{c}\text { Malign } \\
\text { Melanom } \\
\end{array}$ & 3. göz kapağı & Lokal eksizyon \\
\hline 9 & $\begin{array}{l}\text { Simental, } 5 \text { Yaş, } \\
+\end{array}$ & $x$ & & $\begin{array}{l}\text { Yüzeyden taşkın, } \\
\text { eroziv, purulent } \\
\text { akıntıyla birlikte } \\
\text { kanamalı }\end{array}$ & $\begin{array}{l}\text { İndiferensiye } \\
\text { Yassı Hücreli } \\
\text { Kanser }\end{array}$ & $\begin{array}{l}\text { Tüm bulbus okuli ve } \\
\text { perioküler dokular }\end{array}$ & $\begin{array}{l}\text { Bulbus okulide geniş } \\
\text { lezyondan dolayı } \\
\text { operasyon } \\
\text { yapılmadı }\end{array}$ \\
\hline
\end{tabular}

Vakaların anamnezine göre kırmızı-pembe renkli anormal doku kitle ve şişkinlikleri, ortalama 411 ay arasında devam etmekteydi. Süt veriminde azalma, ağılık kaybı, irinli akıntı, değişen karakterde gözyaşıyla birlikte zamanla çoğalan progresif genişleyen hafif çıkıntılı lezyonlar şeklindeydi (Şekil $1,2)$. Oluşan kitleler oküler ve perioküler dokuların fonksiyonunu etkilemekte ve değişik derecelerde görüşü engellemekteydi.

Cerrahi Yöntem: Tedavi amacıyla 4 vakada lokal tümör eksizyonu ve 4 vakada göz enüklasyonu uygulanırken 1 vakada bulbus oculi ve çevre dokulardaki geniş tümör invazyonlarından dolayı kesime sevk önerildi. Tüm cerrahi müdahaleler için $0.1 \mathrm{mg} / \mathrm{kg}$ dozunda kasiçi yolla ksilazin hidroklorür (Rompun, Bayer, Türkiye) ile sedasyon uygulandı. Lokal eksizyonda 3. göz kapağı tabanına lidokain $\mathrm{HCL} \% 2$ (Adokain, Sanovel, Türkiye) enjekte edilerek lokal infiltrasyon anestezi sağlandı. 3. göz kapağı penslerle tutularak dışa doğru çekildi ve küt uçlu eğri makaslar kullanılarak tümöral kitlenin arkasında taban kısmından eksize edildi. Adrenalin emdirilmiş steril hidrofil gazlı bezle tampon yapılarak kanamalar kontrol edildi. Postoperatif dönemde 5 gün süreyle basitrasin 2500 U.I. ve neomisin sülfat $25 \mathrm{mg}$ (Thiocilline ${ }^{\circledR}$, İbrahim Hayri, Türkiye) içeren göz pomadı uygulandı.

Enüklasyon da ise lidokain $\mathrm{HCL} \% 2$ (Adokain, Sanovel, Türkiye) ile retrobulbar blok anestezi uygulandı. Alt ve üst gözkapaklarının sürekli dikişle birbirine dikilmesinin ardından gözkapakları sınırından $1 \mathrm{~cm}$ uzaklıkta eliptik ensizyon yapıldı. Küt diseksiyonla retrobulbar dokular ve bulbus okuli çevresindeki kaslar diseke edildi. Muskulus. retraktor bulbi ve nervus optikus, eğri uçlu penslerle tespit edilerek pensler ve bulbus okuli arasından kesildi. Bulbus okuli orbitadan dışa doğru çekildikten sonra 3. göz kapağı ve harder bezi uzaklaştırıldı. Kanamalar kontrol edildi ve medial açıda fitil dren için küçük bir açıklık bırakılarak gözkapakları basit ayrı dikişlerle birbirine dikildi (Shaw-Edwards, 2010; Weaver ve ark., 2005). Postoperatif dönemde tüm vakalara prokain 
penisilin G ve benzatin penisilin G (Procastrep $^{\circledR}$, Vetaş, Türkiye) $10.000 \mathrm{lU} / \mathrm{kg}$, dihidrostreptomisin sülfat $10 \mathrm{mg} / \mathrm{kg}$ dozda kasiçi yolla 5 gün ve meloksikam (Metacam ${ }^{\circledR}$, B. Ingelheim, Türkiye) 5 $\mathrm{mg} / \mathrm{kg}$ dozda damar içi tek enjeksiyon şeklinde kullanıldı. Operasyon sonrası 6. aya kadar hasta sahiplerinden bilgi alınarak vakalar takip edildi.

Histopatolojik Yöntem: Cerrahi müdahaleyle alınan 9 biyopsi örneği histopatolojik muayene için patoloji laboratuvarına gönderildi. \%10'luk tamponlu formaldehitte tespit edilen örnekler rutin patoloji doku takibine alındı ve parafinde bloklandı. Hazırlanan bloklardan Leica RM 2125 RT microtome ile 5 mikron kalınlığında seri kesitler alınarak deparafinize ve dehidrasyon amacıyla ksilolden ve dereceli alkol (\%50, \%75, \%96, \%100) serilerinden geçirilerek hematoksilen-eosin (H\&E) ile boyandı. Hazırlanan preparatlar ışık mikroskopta (Olympus BX53) ve yüksek çözünürlüklü kamera altında (Olympus DP73) X20 ve X40 objektifler ile incelendi.

\section{Bulgular}

Cerrahi müdahale gerçekleştirilen 9 sığırda oküler ve perioküler tümörlerin klinik ve histopatolojik karakteristikleri ile uygulanan tedavi prosedürü Tablo 1'de özetlenmiştir.

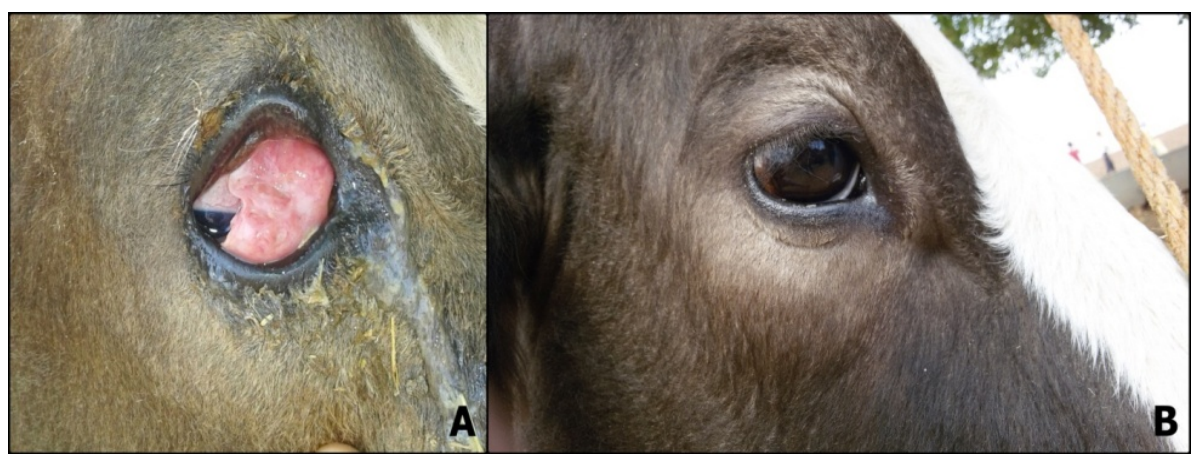

Şekil 1A. Vaka 4 Operasyon öncesi tümörün klinik görünümü.

Şekil 1B. Operasyon sonrası 6 . ay görünümü.

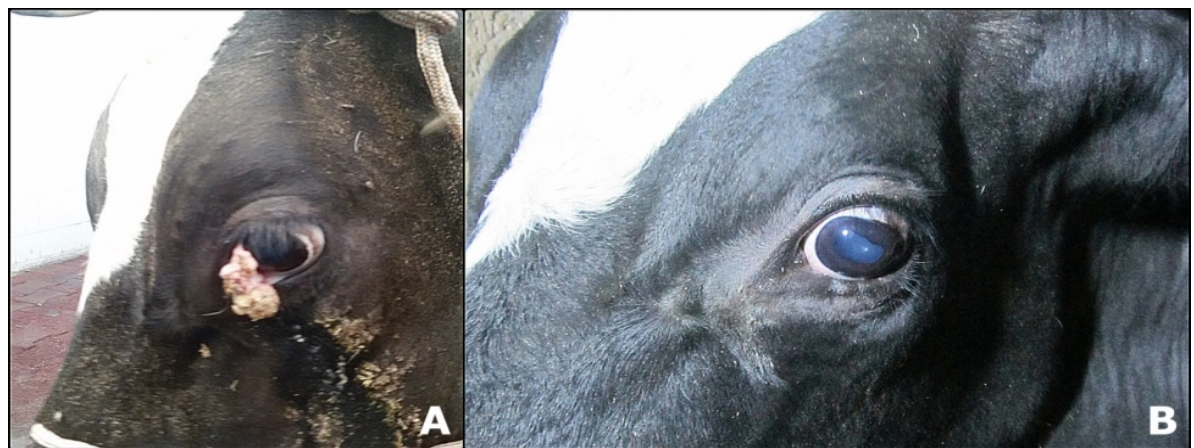

Şekil 2A. Vaka 5 Operasyon öncesi tümörün klinik görünümü.

Şekil 2B. Operasyon sonrası 6 . ay görünümü.

Klinik Bulgular: Hayvanlar ırklara göre incelendiğinde beşinin holstein, birinin simental, birinin Holstein-simental melezi, birinin Güney Anadolu Kırmızısı, birinin Montafon ırkı ve tamamının dişi cinsiyette olduğu belirlendi. Yaşlara bakıldığında birinin 2 yaş, üçünün 4 yaş, üçünün 5 yaş, birinin 6 yaş, birinin 8 yaş olduğu tespit edildi. Lezyonların altısı sağ gözdeyken üçünün sol gözde olduğu gözlendi.

Operasyon sonrası 6. aya kadar yapılan takiplerde olası metastaz, tümör tekrarı veya komplikasyon yönünden herhangi bir bulguyla karşılaşılmadı. Çalışmada değerlendirilen 9 sığırda 6 aylık süre içerisinde metastaz, tümör tekrarı ve komplikasyon parametrelerinde olumsuz bir bulguyla karşılaşılmadığından herhangi bir istatistiksel analize gerek duyulmamıştır.

Histopatolojik Bulgular: Histopatolojik muayeneye göre 4 vakada yassı hücreli kanser, 2 vakada indiferensiye yassı hücreli kanser, 1 vakada melanom ve 2 vakada malign melanom teşhis edildi.

Yassı hücreli kanser olgularında (Vaka 1, 5, 6, 7) epidermisin bir bölgede bütünlüğünü kaybettiği ve bu bölgede çok sayıda hücre artıkları ile nötrofil lökositlerden oluşan yangısal hücre infiltrasyonları görüldü. Ayrıca hiperkromatik çekirdekli, büyük, ovoid şekilli, solgun eozinofilik sitoplazmalı anaplastik epitel hücrelerinden oluşan neoplastik 
hücre adacıklarının merkezinde keratin birikimleri (glob corne) dikkati çekti (Şekil 3B).

Indiferensiye yassı hücreli kanser olgularında (Vaka 2, 9) çok sayıda hiperkromatik çekirdekli, büyük, ovoid şekilli, solgun eozinofilik sitoplazmalı str. spinozum hücrelerinden oluşan neoplastik hücrelerin adacıklar şeklinde dizildikleri ve yer yer bu adacıkların arasında lenfosit, makrofaj ve tek tük nötrofil lökositlerden oluşan yangısal hücre infiltrasyonları dikkati çekti (Şekil 3A).

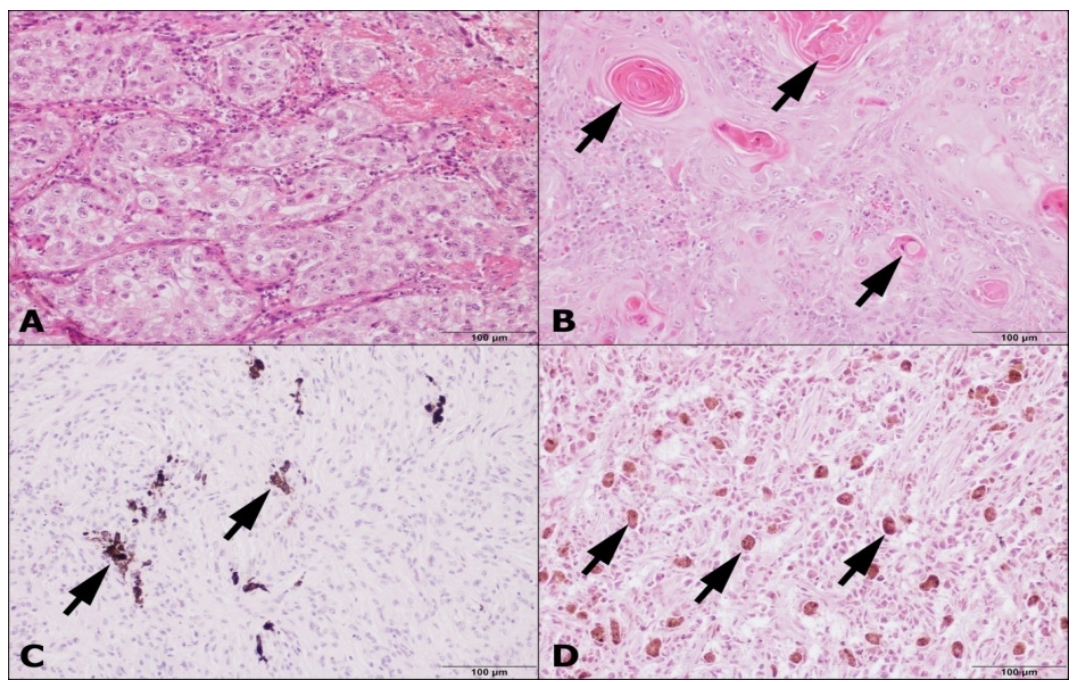

Şekil 3 A. İndiferensiye yassı hücreli kanser: Adacıklar şeklinde dizilmiş anaplazik squamöz hücreler. HxE. B. Yassı hücreli kanser: Çok sayıda atipik skuamöz hücre adacıkları arasında globe corne yapıları (oklar). HxE. C. Melanom: Geniş stroma arasında melanositik hücreler (oklar). HxE. D. Malign melanom: Çok sayıda gelişi güzel dağılım gösteren anaplazik melanositik hücreler (oklar). HxE.

Melanom olgularında (Vaka 3) epidermis ve dermiste çok sayıda koyu kahve-siyahımsı renkte, lapa ya da granüler tarzda melanin pigmenti içeren, çevresinden bağdokudan kapsülle çevrelenmiş atipik melanositlere rastlandı (Şekil 3C).

Malign melanom olgularında (Vaka 4, 8) geniş trabekül yapılarının aralarında değişik yönlere seyreden trabeküller arasında çok sayıda koyu kahve-siyahımsı renkte, lapa ya da granüler tarzda melanin pigmenti içeren pleomorfik melanositik hücrelerle karşılaşıldı (Şekil 3D).

\section{Tartışma ve Sonuç}

Oküler ve perioküler bölgeden köken alan tümörlerle ilgili yaptığımız çalışmada literatür verilerle uyumlu olarak en fazla yassı hücreli kanser (kanser göz) vakalarıyla karşılaşıldı (Ceylan ve ark., 2011; Crispin, 2005; Dubielzig, 2002; Gelatt, 2005; Gharagozlou ve ark., 2007; Martins ve Barros, 2014). Pugliese ve ark. (2014) İtalya'nın güney Sicilya bölgesinde Simental ırkında yaptıkları çalışmada karşılaştıkları oküler ve perioküler tümörlerin tamamının yassı hücreli kanser olduğunu belirtmişlerdir. Den Otter ve ark. (1995) tarafından yapılan çalışmada ise periorbital beyaz deriye sahip simental ırkında daha çok yassı hücreli kanser görüldüğü, periorbital pigmentli deriye sahip diğer sığır ırklarında ise daha az görüldüğü bildirilmiştir.
Oküler ve perioküler bölgede karşılaşılan tümörlerle ilgili yapılan çalışmalarda Ceylan ve ark. (2011) Holstein ırkında (\%67), Gharagozlou ve ark. (2007) ise periorbital siyah deriye sahip Holstein Friesian ırkında daha fazla karşılaştıklarını belirtmiştir. Çalışmamız bu çalışmalarla uyumlu şekilde Holstein ırkı sığırlarda oküler ve perioküler tümörlerle daha sık (\%55.56) karşılaşıldığını göstermektedir.

Yassı hücreli kansere 4 yaşından itibaren rastlanıldığı en sık olarak 7-9 yaş aralığında Hereford, Simental, Holstein-Friesian ırklarında görüldüğü ve diğer ırklarda nadir karşılaşıldığı bildirilmiştir (Al-Asadi, 2012; Ceylan ve ark., 2011; Crispin, 2005; Dubielzig, 2002; Gelatt, 2005; Gharagozlou ve ark., 2007; Pugliese ve ark., 2014). Mevcut çalışmada tespit edilen oküler ve perioküler tümörlerin yaş, cinsiyet ve etkilenen göz yönünden elde edilen bulguların dağılımı literatür verileriyle uyum sağlamaktadır. Yassı hücreli tümörler multifaktöriyel bir etiyolojiye sahiptir ve kalıtım, güneş ışı̆̆ı, beslenme, gözkapağı pigmentasyonu, çevresel koşullar etiyolojide önemli rol oynamaktadır. UV ışığa maruz kalma ve yüksek enerjili rasyonlarla beslenme tümör oluşumunu hızlandırmaktadır (Al-Asadi, 2012; Crispin, 2005; Dubielzig, 2002; Gelatt, 2005). Ceylan ve ark., (2011) tarafından yapılan çalışmada yüksek rakım, ekvatora coğrafi yakınlık, yüksek ortalama sıcaklıklar, hayvanların güneş altında uzun süre otlamadan dolayı yoğun solar radyasyona maruz 
kalmasının oküler ve perioküler tümörlere predispozisyon sağladığı bildirilmiştir. Gharagozlou ve ark. (2007) İran'da yapmış oldukları çalışmada sıcak ve kuru iklim koşullarına sahip Tahran ilinde sütçü sığırlarda oküler tümörlere daha fazla rastlandığı, coğrafi koşullara göre oküler tümör insidensinin değiştiği, sıcak ve kuru bölgelerde güneş ışığına daha uzun süre maruz kalmanın predispoze bir faktör olarak etkidiğini bildirmiştir. Tsujita ve Plummer (2010) tarafından Amerika Birleşik Devletleri'nde yapılan araştırmada ise coğrafi olarak yassı hücreli kanser prevalansının değiştiği, bu değişimde coğrafi şartların etkili olduğu, ülkenin güneybatı bölgesinin yüksek rakım ve düşük enleme sahip olmasından dolayı daha yüksek seviyede güneş ışığına maruz kaldığı, bu durumunda oküler tümörleri tetiklediği bildirilmiştir. Pugliese ve ark. (2014) sıcaklık değişimlerinin $0-40^{\circ} \mathrm{C}$ arasında, günlük ortalama güneş ışı̆̆ı periyodunun 8-10 saat olduğu güney Sicilya'da, AlAsadi (2012) ise sıcaklık değişimlerinin $0-50^{\circ} \mathrm{C}$ arasında, günlük ortalama güneş ışığı periyodunun 9-14 saat olduğu Bağdat çevresinde daha sık oküler ve perioküler tümörle karşılaşıldığını aktarmıştır. Anderson ve Badzioch (1991) sığırlarda solar radyasyon ve yassı hücreli kanser arasındaki bağlantı yönünden yaptıkları çalışmada hastalığın gelişiminde solar radyasyonun önemli bir role sahip olduğunu ve gözdeki pigmentasyonun UV radyasyonun zararlı etkilerinden korunmada önemli olduğunu vurgulamışlardır. Çalışmamızı oluşturan sütçü sığırların tamamının barındırıldığı Şanlıurfa ili deniz seviyesinden ortalama $550 \mathrm{~m}$. yükseklikte, 37.1608 enlem ve 38.7863 boylamda bulunmaktadır. Şanlıurfa ilinin yaz ve sonbahar aylarında kuru ve sıcak hava, kışları ise nispeten soğuk hava şeklindeki çevresel koşulları ile ortalama 327 güneşli gün sayısı ve günlük ortalama 8.3 saat güneş ışığı alması (Anonim2016a, b), yazarların belirttiği coğrafi şartlara yakınlığı nedeniyle oküler ve perioküler tümörlere predispozisyon yaratmaktadır.

Sığırlarda oküler ve perioküler bölgede tümör lokalizasyonu açısından en çok etkilenen anatomik bölgeler sırasıyla Martins ve Barros (2014) gözkapakları, kornea ve 3. göz kapağı, Gharagozlou ve ark. (2007) membrana niktitans ile palpebral konjuktiva, Pugliese ve ark. (2014) ise bulbar konjuktiva, kornea ve limbus kısımlarıdır. Çalışmamızda en sık olarak 3. gözkapağı ve alt/üst palpebral konjuktivada lokalize olan tümörler Martins ve Barros (2014) tarafından bildirilen sonuçlarla uyum sağlamaktadır. Yassı hücreli kanser genellikle lokal radyoterapi veya cerrahi müdahalenin kriyoterapi veya radyoterapiyle birlikte kullanılmasıyla tedavi edilebilir (Crispin, 2005). Hirsbrunner ve ark (1998) tarafından yapılan araştırmada 21 sığırın 17'sinde bulbus ekstirpasyonu, 2'sinde kriyoşirurji uygulandığı diğer 2 'sinde ise ekonomik nedenlerden dolayı tedavi edilmeyerek kesime sevk edildiği bildirilmiştir. Operasyondan sonraki ortalama yaşam süresinin 15 ay olduğu ve hayvanın verim süresini uzatmak için yassı hücreli kanserde bulbus ekstirpasyonunu önermektedirler. Sloss ve ark. (1986) tarafından Hereford ırkında yassı hücreli kanserin kontrolüyle ilgili incelenen 3 sürüde $3 \mathrm{~mm}$ çaptan daha büyük yassı hücreli kanser lezyonlarının kriyoşirurji ile tedavi edildiği, bir veya iki uygulama yapıldıktan sonra lezyonların \%71'inin regrese olduğunu bildirmiştir. Tarafımızdan yapılan çalışmada 4 vakada lokal tümör eksizyonu ve 4 vakada göz enüklasyonu uygulandı. Postoperatif 6 ay süreyle yapılan takiplerde herhangi bir komplikasyonla karşılaşılmadı.

Sonuç olarak; sığırlarda gelişen oküler ve perioküler tümörlerin en sık karşılaşılanı olan yassı hücreli kanser simental ırkından başka ırklarda da görülebilir. Oküler ve perioküler tümörlerin tedavisinde eksizyon ve enuklasyon maliyeti düşük, basit ve az ekipmanla kolay uygulanabilir cerrahi yöntemlerdir. Oküler ve perioküler bölgedeki ileri tümöral hastalıklarda ağrıyı azaltmak, hayvanın yaşam kalitesini yükseltmek, ekonomik kayıpları azaltmak ve verim süresini arttırmak amacıyla kullanılabilir.

\section{Kaynaklar}

Al-Asadi RN, 2012: A survey and treatment of ocular carcinomas in Iraqi dairy cows from (1987-2012). Kufa Journal for Veterinary Medical Sciences, 3, 2, 66-77.

Anderson DE, Badzioch M, 1991: Association between solar radiation and ocular squamous cell carcinoma in cattle. Am J Vet Res, 52, 5, 784-788.

Anonim, 2016b: T.C. Enerji ve Tabi Kaynaklar Bakanlı̆̆ı, Yenilenebilir Enerji Genel Müdürlüğü, Güneş Enerjisi Potansiyel Atlası (GEPA), http://www.eie.gov.tr/ MyCalculator/pages/63.aspx, Erişim tarihi; 25.11.2016

Canpolat I, Yaman I, Gunay C, 2007: A case of primary intraocular malignant iris melanoma in an Akkaraman sheep. Revue Med Vet, 158, 4, 171-173.

Ceylan C, Ozyıldız Z, Yılmaz R, Biricik HS, 2012: Clinical and histopathological evaluation of bovine ocular and periocular neoplasms in 15 cases in Sanlıurfa region. Kafkas Univ Vet Fak Derg, 18, 3, 469-474.

Crispin S, 2005: Farm Animal Ophtalmology. In "Notes on Veterinary Ophtalmology", First Ed, Blackwell Science Ltd, Oxford, pp. 239-264.

Den Otter W, Hill FW, Klein WR, Everse LA, Ruitenberg EJ, Van der Ven LT, Koten JW, Steerenberg PA, Faber JA, Rutten VP, 1995: Ocular squamous cell carcinoma in Simmental cattle in Zimbabwe. Am J Vet Res, 56, 11, 1440-1444. 
Dubielzig RR, 2002: Tumors of the eye. In "Tumors in Domestic Animals", Ed; Meuten DJ, Fourth Ed. lowa State Press, lowa USA, pp 739-754.

Gelatt KN, 2005: Neoplasia of the eye and associated structures. Eye and ear. In "The Merck Veterinary Manual", Ed; Kahn CM, Ninth Ed, Merck\&Co., Inc, Philadelphia, pp. 413-416.

Gharagozlou MJ, Hekmati P, Ashrafihelan J, 2007: A clinical and histopathological study of ocular neoplasms in dairy cattle. Vet Arhiv, 77, 5, 409-426.

Hirsbrunner G, Ebeid M, Eicher R, 1998: Cancer eye in cattle: 21 cases (1990-1996). Schweizer Archiv fur Tierheilkunde, 140, 4, 149-155.

Martins TB, Barros CSL, 2014: Fifty years in the blink of an eye: a retrospective study of ocular and periocular lesions in domestic animals. Pesq Vet Bras, 34, 12, 1215-1222.

Ozmen O, Sirin Sengöz O, Çınar H, Dolu H, 2016: Retrobulbar fibrosarcoma in a sheep. Acta Veterinaria-Beograd, 66, 2, 265-270.

Pugliese M, Mazzullo G, Niutta PP, Passantino A, 2014: Bovine ocular squamous cellular carcinoma: A report of cases from the Caltagirone area, Italy. Vet Arhiv, 84, 5, 449-457.

Robert SM, 2002: Ocular neoplasia. In "Large Animal Internal Medicine", Ed; Smith BP, Third Ed, Mosby Inc, Missouri, pp. 1192-1199.
Sabri MA, Shahzad M, Quayyum A, 2010: Ocular melanoma in a buffalo: A clinical case recorded under field conditions. Buffalo Bulletin, 29, 3, 235237.

Sağlıyan A, Günay C, Han MC, Özkaraca M, 2010: Sığırlarda oküler yassı hücreli karsinom olgusu: iki olgu. XII. Ulusal Veteriner Cerrahi Kongresi Özet Kitabı, Antalya.

Schulz KL, Anderson DE, 2010: Bovine Enuclation: A retrospective study of 53 cases (1998-2006). Can Vet J, 51, 611-614.

Shaw-Edwards R, 2010: Surgical treatment of the eye in farm animals. Vet Clin Food Anim, 26,459-476.

Sloss V, Smith T J S, Gao De Yi, 1986: Controlling ocular squamous cell carcinoma in hereford cattle. Australian Veterinary Journal, 63, 8, 248-251.

Tsujita H, Plummer CE, 2010: Bovine ocular squamous cell carcinoma. Vet Clin Food Anim, 26, 511-529.

Weaver AD, Jean G, Steiner A, 2005: Bovine Surgery and Lameness. Second Ed., Blackwell Publishing, Oxford, UK.

Wilcock BP, 1993: The eye and ear. In "Pathology of Domestic Animals", Eds; Jubb KVF, Keneddy PC, Palmer N, Fourth Ed, Academic Press, San Diego, pp.512-515.

*Yazışma Adresi: Ünal YAVUZ

Harran Üniversitesi Veteriner Fakültesi,

Cerrahi Anabilim Dalı, Şanlıurfa, Türkiye.

e-mail: unalyavuz@harran.edu.tr 